\title{
Részlet Berényi István életútinterjújából, szakmai pályájára fókuszálva
}

\author{
Life story interview of István Berényi \\ (excerpts, focusing on his scientific career)
}

\author{
BÖGRE ZSUZSA, FEKETE ATTILA
}

\author{
„Aki nem hagyja magát elveszni, \\ csak az nincs elveszve"
}

Hogyan döntötted el, hogy földrajzzal fogsz foglalkozni?

Az érettségitől lendületet kaptam, hogy tovább kellene tanulni, de nem volt határozott elképzelésem, csak az, hogy tovább szeretnék tanulni. Mivel rengeteg dolog érdekelt, nem tudtam eldönteni, hogy magyar-történelem vagy földrajz-geológia legyen az irány. Előzetesen próbálkoztam a Képzőművészeti Főiskolával, de az nem sikerült. Végül is a földrajz-geológia mellett döntöttem, és ott is a geológia érdekelt jobban. Úgy éreztem, a debreceni felvételi különösen jól sikerült. Matematikából-fizikából volt a vizsga, földrajzból alig kérdeztek. Mindenképp rá akartak venni arra, hogy matematikára menjek. Hogy miért, nem tudom. A fizikát kifejezetten szerettem. De én kitartottam amellett, hogy nem, akkor inkább nem tanulok tovább, nekem az nem megy. Így felvettek földrajz-geológiára, 16 embert, 8 fiút, 8 lányt. Az első év még nagyon nehezen ment, amíg be nem illeszkedtem ebbe az új tanulási mechanizmusba. Akkor még jegyzetek nem voltak, meg kellett tanulni az előadásokon jegyzetelni.

Két évet végeztünk el a földrajz-geológia szakon. A 2. év után elvették a geológiát, azt mondták, hogy geológusra nincs szükség. Vagy csak földrajzosként végzünk, vagy felvesszük a történelmet is. Néhányan felvettük a történelmet. Ezért 1957-ből van a diplomám földrajzból, és 1959-ből van a diplomám történelemből.

Nagyszerű tanárokat kaptam az egyetemen, kiváló képességű emberek voltak. Geológiából rettegtünk ugyan Földvári Aladártól ${ }^{1}$, de nagyszerü ember volt. Rendkívül szerettem a kristálytant, a kedvencem volt, úgy éreztem, hogy a geológiával fogok kezdeni valamit. Földrajzos tanáraim közül különösen nagyszerü volt Kéz Andor ${ }^{2}$ természet-földrajzos Pestről, akit az ELTE-ről rúgtak ki. A másik tanárom Kádár László ${ }^{3}$ volt, a II. világháború után helyezték Debrecenbe. Annak idején Telekinek volt a tanársegédje, Almássy Lászlóval

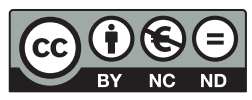


volt Afrikában, a líbiai sivatagi utakat térképezte. Az idős generáció igen nagy hatással volt ránk. Távolságtartóak voltak ugyan, de nagyon segítőkészek.

\section{Az egyetem után hogyan kerültél tudományos pályára?}

Amikor befejeztem az egyetemet 1957-ben, akkor ott lehetett volna maradni az egyetemen. Kádár László demonstrátora voltam, szerette volna, hogyha ottmaradok tanársegédnek. Őszintén szólva nem volt hozzá kedvem. Kádár László rendkívül szellemes ember volt, nagyon nagy tudású, széles látókörű, de „táblatörlőnek”, ahogyan akkor mi hallgatók láttuk, nem akartam maradni. Úgy gondoltam, hogy a tanárnak önálló egzisztenciája van. Kimegyek a katedrára, és az órán azt mondok, amit tudok. Tanárnak készültem, és vágytam arra, hogy tanár legyek. Elmentem Kiskőrösre tanítani, ezért megharagudott rám Kádár László, egy pár évig a folyosón sem állt velem szóba. De egy idő után kezdett bennem megfogalmazódni, hogy tudományos dologgal kellene foglalkozni. A feleségem is többször kérdezgette, hogy miért nem csinálod, miért hagytad abba. 1960-ban aztán megkerestem Kádár Lászlót, hogy gazdaságföldrajzzal tudnék foglalkozni, most indulnak a szövetkezeti átalakítások a kiskőrösi járásban, illetve Bács megyében. Nem termelöszövetkezetek, hanem szakszövetkezetek lesznek, ezért szívesen foglalkoznék agrárföldrajzzal. „Akkor menjen Enyedihez” mondta Kádár László. Enyedi György akkor már Debrecenben tanított. Jelentkeztem nála, nagyon kedvesen fogadott. A levelezésünk kezdettől fogva mindmáig megvan. Ő bátorított, hogy van fantázia az agrárföldrajzban. Enyedi György akkortól kezdve már bekapcsolódott a Nemzetközi Földrajzi Unió (IGU) ${ }^{4}$ agrárföldrajzi szakbizottságába. Ott az elnök egy lengyel professzor volt, Kostrowiczky. ${ }^{5}$ Attól kezdve kezdtem el művelni az agrárföldrajzot. 1961-ben szereztem az egyetemi doktorit. Utána elkezdtem a tematikus térképezést. Valójában arra gondoltam, hogy ezt a témát lehetne kandidátusivá vinni tovább. Akkor Enyedi azt javasolta, hogy ha a doktorim a szőlőtermesztés volt, akkor terjesszük ki ezt a témát regionális értelemben, és legyen Délkelet-Európa szőlőtermelése ${ }^{6}$. A kandidátusira, amire én jelentkeztem 1965-ben, felvettek Délkelet-Európa szőlötermelése kutatási témára. A témavezető Enyedi György lett. Ő azután fantasztikus ügyesen tudta az én nemzetközi dolgaimat kézbe venni és irányítani. Kilátogatott hozzám Kiskőrösre Kostrowiczky is. Megnézte azt a kiskőrösi térképet, ami aztán angolul, németül, magyarul is megjelent, és terepbejárásra épült. A XVIII. század végétől kezdve a II. József korabeli katonai térkép-felvételezések alapján a kultúrtáj és a társadalmi struktúraváltás összefüggéseit ábrázolta és értelmezte. Ez akkor nagyon újszerủ volt. A német kollégáknak és Kostrowiczky professzornak is tetszett. Attól kezdve én ebben az agrárföldrajzi társaságban jelen tudtam lenni. Kostrowiczky, illetve Enyedi szerveztek Kaštel Stari ${ }^{7}$ környékén egy terepbejárást, ami ezeknek a tematikus térképeknek a módszertanát hivatott továbbadni, összehangolni. Engem is kivittek oda. Ez nagy ugrás volt a nemzetközi kapcsolatokban. A kollégák Jugoszláviából; Ilesič ${ }^{8}$ Zágrábból, Klemenčic, ${ }^{9}$ Ljubljanából; ők már akkor ennek a kultúrtájelemzésnek a szociál-ge- 
ográfiai aspektusát követték, aminek München volt a központja. Így kerültem később a müncheniekhez közelebb. Akkor még az volt az elképzelésem, hogy mindezt meg lehet csinálni légi fényképek alapján. Nem kell, hogy bejárjam az egész területet, ami nagyon munkaigényes, hanem légi fényképekkel lehet a tájszerkezetet elemezni. 1968-69-től kezdve megalakult a Légifénykép-interpretáció Nemzeti Bizottsága Magyarországon, Mike Zsuzsa ${ }^{10}$ volt a vezetője. Ebbe is belekerültem, és végeztem a földhasználati struktúraelemzést légifényképek alapján ${ }^{11}$. Megjelent tanulmányom, és Drezdában voltam egy nemzetközi konferencián. Ott megismertem Sigfried Schneidert, ${ }^{12}$ aki azt mondta, ha ösztöndíjat tudok szerezni, akkor szívesen látna ebben a témában Németországban. De ahhoz meg kellett lenni a kandidátusinak, mert csak minősítetteket vesznek fel Humboldt-ösztöndíjra. Időközben elkészült „Délkelet-európai szocialista országok szőlőtermelése” címmel a kandidátusi disszertációm. Megvédtem a kandidátusit, és jelentkeztem Humboldt-ösztöndíjra. Megkaptam a Humboldt Alapítvány ösztöndíját, de egy évre. Ezzel az egy évvel - ebben Enyedinek igaza lett - megalapoztam a szakmai pályafutásomat.

Miután hazajöttél, mégis szakterületet váltottál, ami végül a szociál-geográfia magyarországi meghonositásához vezetett. Hogyan történt ez?

Amikor hazajöttem, megtanulva a légifénykép-interpretációt, akkor arra gondoltam, most az intézetben is létrehozunk egy ilyen csoportot, részleget. De mire hazaértem, teljes egészében megváltozott a politikai hangulat. Kimentem 1971-ben, hazajöttem '72-ben, addigra Mike Zsuzsát elküldték, feloszlatták az interpretációval foglalkozó bizottságot. De akkor már a tarsolyomban volt a szociál-geográfia. Kik miért hagyták el a földterületet, hogyan következett be a tulajdonok elhagyása, kinek hol van tulajdona még a határban, miért van parlagon, innen van a parlagföldekkel való kutatásom, ami megjelent németül is. Azt mutattam ki, hogy nálunk a parlagterület nem úgynevezett szociális parlag, nem a társadalmi struktúraváltás következtében van parlag a határban, hanem azért, mert a téeszesítés révén az emberek rájöttek, hogy bekövetkezett ugyan egy társadalmi struktúraváltás is, de a tsz-ek számára nem gazdaságos minden földet megművelni. ${ }^{13}$ A tulajdonos nem saját döntése alapján szabadult meg a tulajdonától, mint Saabrüden környékén, hanem a tsz-szervezés miatt. Inkább egy gazdasági parlagnak volna tekinthető, nem pedig társadalmi parlagnak, mint ahogy Harthe leírta. Ahogyan elkezdtem a szociál-geográfiával kacérkodni, azt tanácsolták - kolléganőm Lettrich Edit is -, hogy Münchenben Rupperttel ${ }^{14}$ vegyem fel a kapcsolatot. Ő volt akkor a háború utáni német szociál-geográfia ismert képviselője, a „müncheni iskola” alapítója.

Enyedi Györggyel megbeszéltem, ő volt az igazgatóhelyettes, hogy én hogyan váltanék. Mit szól hozzá, felvegyük-e a kapcsolatot, és hogyan csináljuk? Azt mondta, nagyon jó, nagyon okos. Csináljuk meg! Attól kezdve elkezdtünk szervezni egy bajor-magyar földrajzi szemináriumot. ${ }^{15} \mathrm{Ez}$ a '80-as évek végéig ment, és én szerveztem. Azt jelentette, hogy kétévenként mi voltunk ott, két év 
után ők jöttek ide mihozzánk. Közös projektjeink nem nagyon voltak, de hasonló témájú, tematikájú anyagaink igen. München közelében, Tutzingenben volt a szeminárium.

Attól kezdve több alkalommal kint jártam 3-3 hónapos ösztöndíjjal Ruppertnél. Nagyon jól összejöttem azzal a társasággal. Mindmáig levelezek a kollégákkal, akik ott voltak. Nagyon bensőséges munkakapcsolat alakult ki a müncheniekkel. Amikor nálunk volt a bajor-magyar találkozás, akkor igyekeztem bekapcsolni az NDK-sokat, lipcseieket, egy-egy kollégát meghívtam. A veszprémi akadémiai intézetben rendeztünk egy ilyen „közös” szemináriumot. Meghívtuk a pozsonyiakat is. Egy kicsit próbálta az ember tágítani a kétoldalú kapcsolatot. Ez a '70-es évek második fele, a '80-as évek első fele, kb. 10 év, ami rajtam nagyon sokat lendített. Ebben az időszakban történt, hogy Simó Tibor megkeresett (1978-ban), akkor ő már Pesten volt a Társadalomtudományi Intézetben, hogy csináljunk együtt faluvizsgálatokat, és én készítsem a tematikus térképeket. Neki van kutatási pénze, és teljes körü felméréseket tudunk végezni a kiválasztott falvakban. Akkor dolgoztuk fel Tardot. Azután következett Királyhegyes. Ezt követően Tiszakécskén végeztünk teljes körű lakossági lekérdezést. Ez az anyag lett az akadémiai doktorim alapja, amelyet Münchenben tudtam befejezni.

1983-tól kezdtem átállni a szociál-geográfia elméleti kérdéseire, amikorra volt már 10 éves empirikus kutatásom.

Hogyan élted meg az 1984-es „szakadást”, az FKI-RKK szétválását? Te miért maradtál az FKI-ban?

1984-ben a csoport nagy része kivált a mi intézetünkből, önálló intézményrendszer épült fel, aminek volt már előzménye, mert a békéscsabai intézet már korábban létrejött, de még az FKI keretei között. Amikor létrejött az RKK, valójában a Dunántúli Tudományos Intézet lett a központja. Ehhez kapcsolódott Békéscsaba, majd megalakult az Alföldi Intézet Kecskeméten, és ment ennek a hálózatnak a kiépítése tovább. Ezzel a földrajziból kikerültek a korábbi területfejlesztési programok.

Nehéz félév volt, amíg ezt végiggondoltam. Egy valamiben biztos voltam, hogy nem tudok a földrajztól elszakadni. A regionális tudományokat valahogy nem tudtam megfogni. El nem tudtam képzelni, hogy a földrajz létezik regionalizmus nélkül. De azt sem tudtam elképzelni, hogy a régió mint önálló tudomány létezhet földrajz nélkül. Természeti tér - gazdaság - társadalom, ez a hármas struktúra történetileg változó folyamatban, de mindig jelen van, és kölcsönkapcsolat-rendszert alkot, én ettől nem tudtam elvonatkoztatni. Az a regionális szemléletmód, amit a közgazdaságtan vagy igazgatásstruktúra statisztikai adatok alapján elemez, gyakran elvonatkoztatva az embertől, elvonatkoztatva a természeti tértől, az engem nem vonzott. Nem éreztem akkor át, hogy ez mennyire fontos. A földrajzot meg sajnáltam mint intézményt. De az is fájt, hogy nem tudtam menni a társasággal. Talán az is munkált bennem, hogy feladták a leckét: én szervezzem újra a társadalom-földrajzi típusú 
osztályt. Enyedi György is amellett volt, hogy „,ha te ebben nem látsz akkora fantáziát, akkor maradj itt, és szervezd újra az osztályt". Enyedi ebben a dologban is nagyon megértő volt. Azt mondta, támogat abban, hogy én azt újraszervezzem.

Enyedivel elment az osztály, amiben együtt dolgoztunk a '70-es évek elejétől kezdve: Barta Györgyi, Beluszky Pál, Sikos T. Tamás, Mészáros Júlia, Tiner Tibor, Bassa László. Volt egy 6-7 fös osztályunk, akik a 70-es évek második felében az elmaradott területeket vizsgálták, és még a 80-as évek elején is együtt dolgoztak. Sok mindent megtanultam Enyedi Györgytől, hogyan építi ki a csoportot, hogyan mozgatja az embereket, hogyan szervezi meg számukra a kutatási lehetőségeket. Soha nem mondta, hogy ezt szabad, azt nem szabad csinálni. Azt megmondta, hogy abban van fantázia vagy nincs. Az én esetemben is. Jó pillanatokban ő mindig nagyon jó tanácsot adott. Egy fél mondat elég volt, hogy azt mondja: ebben van fantázia.

Az RKK megalakulásával szétesett ugyan a társaságunk az FKI-ban a '80-as évek közepén, a régiek közül maradtunk ott talán hárman: Tiner Tibor, Bassa László, Perger Éva. Ez viszont nekem adott nagy lehetőséget, mert már a '80-as évek elejétől tanítottam a debreceni egyetemen. Ott tűnt már fel nekem Cséfalvay Zoltán, Kocsis Károly, Kovács Zoltán, később Michalkó Gábor. A megüresedett állásokra az FKI-ba jöhettek a fiatalok. Újra tudtuk szervezni a társadalom-földrajzi osztályt. Csatlakozott hozzánk még Pomázi István, Iván László, Kiss Éva Edit. Megpróbáltuk a társadalmi alapfunkciók szerint egymás közt felosztani a feladatokat. Nagy nyereség volt, hogy Békéscsabáról a tapasztalt Dövényi Zoltánt sikerült elhívni. Így állt össze egy olyan osztály, amely 1986-tól az intézetünk erősségét adta. Mindez lehetővé tette a szélesebb körű nemzetközi együttműködést. Végül is nagyon jó gárda lett belőlünk.

Hogy kerültél ezek után a Pázmány Péter Katolikus Egyetemre, földrajzos létedre a Szociológia Tanszékre?

Igazgató voltam az FKI-ban, még kijártam Bécsbe tanítani, és elkezdtem oktatni az ELTÉ-n is. Időközben elkezdődött az INTERREG II. c. program ${ }_{1}^{16}$ európai uniós támogatással, ami a határ menti régiók problémáival foglalkozott. Ebbe a munkabizottságba is menni kellett volna, de egy idő után, a '90-es évek végén lemondtam. Eközben elnöke voltam az MTA Földrajzi Bizottságának, az OTKA Földtudományi Bizottságának, a MAB Földtudományi Bizottságának és tag az MTA Doktori Bizottságában, választott képviselő az MTA Közgyűlésében.

Az egészségi állapotomon éreztem, hogy ezt így tovább nem lehet csinálni. Azt mondták az orvos barátaim, hogy kezdd el a visszalépéseket. Ugyanakkor az oktatás egyre jobban izgatott, amit Debrecen után az ELTE-n is folytattam. Próbáltam rábeszélni a kollégákat, hozzunk össze olyan szociál-geográfia szakot, amely elsősorban társadalomtudományi szemléletü, mert a '93-as európai parlamenti határozat értelmében a szubszidiaritásra épülő terület- és településfejlesztést, tervezést fogják támogatni. Nem jött be. Az akadémiai üdülőben 1977-ben véletlenül megismerkedtem Maróth Miklóssal, aki akkor a PPKE BTK 
dékánja volt, és beszélgettünk arról, hogy mi mindent csinálok. A véleménye az volt, hogy két oldalról is lehetne hasznosítani a témát náluk a karon. Jó volna a szociológiába beépíteni, hogy a szakba belekerüljön a település- és a regionális kutatásokkal kapcsolatos társadalmi szemlélet. Másrészt jó lenne a történészeknél a régiótörténetet és a történeti földrajznak azt az irányzatát bekapcsolni, amivel a kultúrtájtörténet kutatásával kapcsolatban foglalkoztam már két évtizede. Kaptam az alkalmon. Így kerültem be Varga Károly Szociológiai Intézetébe, akinek tetszett az ötlet. Ő nagyon jó kapcsolatban volt a Bécsben élő Morell Gyulával ${ }^{17}$ és a német szociológusokkal, ahol tantárgyként szerepelt a szociál-geográfia és a településtudomány a szociológusképzésben. Varga Károlynak az volt a véleménye, hogy próbáljunk összehozni egy olyan struktúrát, amiben ez szakirányt jelent. Ezzel elcsábított engem a Földrajzi Kutatóintézettől. Ahhoz, hogy ennek az elméleti részét össze tudjam rakni, kértem a Széchenyi professzori ösztöndíjat, és megkaptam, de nem az ELTE-re kértem, mivel ott még tanítottam, s tudtam azt, hogy egy másik kolléga is beadta az ELTE-n, ezért felhívtam a titkárságot, hogy én nem az ELTE-re, hanem a PPKE-re kértem. Két nap múlva telefonáltak, hogy valóban a Pázmányra tenném át a Széchenyit? Miért? - Azért, mert egy kolléga beadta az ELTE-n, akit én nagyra becsülök, és neki ott helye van. A PPKE-n pedig új dolgot tudnék csinálni, ha megkapnám. „Hát ilyet még nem is hallottam” - volt a válasz. Ezzel el is volt intézve. Meg is kaptam. Nagyon örültem, mert el tudtam készíteni a funkcionális tér szocio-geográfiai elemzésével foglalkozó tanulmányt, ami már közelebb áll a Morell-féle elképzeléshez. Az ő definíciója szerint a szociál-geográfia az ember térbeli magatartásának tudománya. Ezzel újra „otthonra” találtam. Az a négy év nekem nagyon jól jött, mert közben empirikus vizsgálatokat tudtunk végezni a hallgatókkal: közel 10 szakdolgozat született. Úgy éreztem akkor, nagyon jó döntés, jó váltás volt. Egy különleges sugallat. Hogy nekem ott, akkor kellett találkoznom Maróth Miklóssal. Végiggondoltam, hogy amit összeszedtem a közel 40 év alatt, ezt megpróbálom átadni a hallgatóknak. Valaki vagy fogékony rá, vagy meghallgat, vagy nem, az ő dolga. De megpróbálom értékesíteni a sok év kutatásait. Ez vezetett Piliscsabára.

Másrészt első perctől kezdve megragadott a szellemiség. Senki sem akarta megmondani, hogy mit kell csinálni. Jelzőt nem találok arra, hogy mennyivel szabadabb környezetet találtam ott. Nem volt „külső megbízás”, megrendelői elvárás, teljesítménykényszer stb.

Úgy éreztem, hogy érzékenyebb a hallgatói közeg is, kevesebben vagyunk, jobban lehet a hallgatókkal foglalkozni. Úgy éreztem, hogy számomra ez a lépték jobban kezelhető. Az M. Kiss Sándor vezette Történettudományi Intézetben is nagyon jó hangulatot tapasztaltam. Sohasem éreztették, hogy én „csak” földrajzos vagyok. Nem mintha bármikor problémám lett volna a munkahelyen. De itt Piliscsabán fenntartás nélküli elfogadást éreztem, ami engem meglepett, mert mégiscsak TTK-s vagyok! Hogy jövök én a bölcsészkarra? Két év múlva azt mondták, hogy legyek tudományos dékánhelyettes. Ez is meglepett. Attól tartottam, hogy a 
kollégák nem fogadnak el épp azért, mert „nem odavaló vagyok”. Ezt egyáltalán nem éreztem senki részéről, a Kari Tanácsban sem. Tényleg sok adminisztrációs munkám volt, a minősítéseket vagy az egyetemi tanári felterjesztéseket el tudtam indítani, a PhD-iskola szervezésében részt vehettem stb., ami jó érzéssel töltött el utólag, hogy hasznos munkát végeztem. Megbecsülést éreztem első perctől kezdve, hogy ezt felvállaltam. Nekem nem tűnt áldozatnak, mint egykét geográfus kolléga feltételezte, mondta.

A történettudományi doktori iskola szervezése során - M. Kiss Sándor, Őze Sándor és Pucilowski J. - az volt a vélemény, hogy a történeti regionalizmus mint „mühely” legyen a programban. Ezzel akarva-akaratlanul a munkám súlypontja áthelyeződött a PhD-programra és a történészekkel való együttműködésre, annak ellenére, hogy nem vagyok történész, bár a második szakom az. A földrajzon belül az agrártörténet vagy a történeti földrajz is határeset, de egyre jobban művelt téma. A földrajzi szemléletű történeti földrajz a kultúrtájelemzéssel és annak történetiségével foglalkozik. Az új európai regionalizmus programja értelmében ezt próbálom átvinni a régiótörténetbe. Ha igaz az, hogy a nemzetállamok Európában régiók lesznek, akkor a régiók történetével tisztában kell lenniük az embereknek.

A szociológiánál ez ott folytatódott, hogy beindult a települési szakirány Varga Károly időszakában. Miután ez háttérbe került Varga Károly nyugdíjba vonulásával, az én szerepem is következésképpen elakadt. Hiszen a szociál-geográfiát a szociológia segédtudományának tekintem, mint ahogy vannak szociológiai iskolák Nyugaton, ahol ez tantárgy, a képzés része. A szociológiának szüksége van a szociál-geográfiára, mert a társadalmi magatartás térbeliségét mutatja be, összefüggésbe hozza a különböző funkciók működésével. Ezzel már az emberi magatartásra utalok, sőt az emberek közötti kapcsolatokat is érintem akarva-akaratlanul, hiszen minden ilyen funkcióval kapcsolatban valamiféle csoportmagatartás alakul ki. Akkor közel vagyok a szociológiai gondolkodáshoz. Ezért, ha megnézitek a német nyelvű vitákat, a '70-'80-as években, ott szinte állandó vita tárgya volt az, hogy a szociál-geográfia tulajdonképpen a földrajznak vagy a szociológiának a része? De mindenféleképpen társadalomtudomány, és semmi köze nincs a természettudományos logikai érveléshez. A társadalomtudományok logikája szerint kell végiggondolnom, amit én csinálok, mert nem a természettudományi törvényszerüségek mozgatják az ember térbeli cselekvését a szükségletek kielégítése során, hanem a társadalmiak. Amennyiben azt mondjuk, hogy a szociológiának része a közgazdaságtan vagy a politológia, akkor ugyanúgy része a társadalom tértudománya is. Hiszen az emberi cselekvés a tér nélkül elképzelhetetlen. Kevésbé elemzett az, hogy a tér önmagában milyen hatással van rám. Ezek kevésbé tisztázott dolgok. Engem ez a probléma izgat, mert néhány olyan esettel találkoztam, ami megmagyarázhatatlan az ember és a tér kapcsolatát illetően.

Én a Pázmányon úgy éreztem magam, mint aki megújult. Szakmai szempontból és lelkileg is ez nekem egy harmadik irányváltás volt. Azt mondtam, ez 
a befejezés. Az első váltás az volt, amikor a középiskolából átmentem a tudományos pályára az FKI-ba, és most irányváltás azzal, hogy befejezem, szintetizálni tudom a dolgokat és továbbadni, amit megszereztem. Úgy éreztem, hogy ez így kerek egész. Egy eleve elrendelés. Ez volt és van bennem. Az ember érezze jól magát abban a munkában, amit csinál. Ha az ember azt érzi, hogy mindig van a hallgatók között olyan, akit érdekel, akkor már megérte. Akkor legyen bármekkora nagy a csoport, de ha van egy-kettő, aki óra végén odajön, és azt kérdi, ennek hol nézzek utána, ha azt mondja, ez a dolog érdekel, már megérte. Ezzel a szakmai pályafutásom érzésem szerint teljes ívvé vált.

\section{Jegyzetek}

Földvári Aladár 1949-től a KLTE Ásvány- és Kőzettani Tanszék vezetője, később a Miskolci Nehézipari Műszaki Egyetem tanára, 1951-ben Kossuth-díjat kapott. Kéz Andor 1953-tól egyetemi tanár a KLTE-n, de előadásokat 1949-től tartott.

3 Kádár László 1938-tól Teleki Pál mellett dolgozott. 1939-40 között Győrffy István halála után a Táj- és Népkutató Intézetet vezeti. 1942-től az újvidéki Keleti Kereskedelmi Főiskola tanára. 1947-től a KLTE egyetemi tanára.

4 A Nemzetközi Földrajzi Unió Agrárföldrajzi Bizottsága.

5 J. Kostrowiczky a Lengyel Tudományos Akadémia Földrajzi Intézetének igazgatója.

6 Les typesgéographiques de la viticulture en Europe du Sud-Est. - Bulletin de la SocietéLauguedocienne de Géographie, 2., 1974., 107-129.

7 Kaštel Stari (Jugoszlávia) Split környéki táj, illetve település, ahol a városi polgárok a velencei korszakban szőlőt telepítettek, ezek voltak a košklek.

8 A Zágrábi Földrajzi Intézet igazgatója.

9 I. Klemencic a Ljubljanai Földrajzi Intézet igazgatója.

10 A Légifénykép-interpretáció Magyar Nemzeti Bizottságának elnöke volt.

11 A légifénykép-interpretálás alkalmazási lehetőségei az agrárgazdasági kutatásban - Földrajzi Értesítő XVII. évfolyam, 1968., 1., 133-143.

12 S. Schneider a Bundesforschungsanstalt für Landeskunde igazgatója volt és a Nemzetközi Földrajzi Unió Légifénykép-interpretációs Bizottságának elnöke.

13 A parlagterületek kutatásainak elvi és módszertani problémái - Földrajzi Közlemények, 22, 1974., 2., 198-214.

14 Ruppert, K. a müncheni LMU Földrajzi Intézetének igazgatója volt.

15 A kapcsolat építésében segített Lettrich Edit, aki akkor még az intézetünk munkatársa volt. Ő mintegy „átadta” a müncheni kapcsolatokat, amikor nyugdíjba ment.

16 INTERREG II. c. program az eurorégiók kialakítására és kutatására koncentrált. A programot J. Maier vezette, a Bayreuti Egyetem Földrajzi Intézetének igazgatója.

17 Bécsben élő magyar szociológus. 